version into heat (wasted in space); and this, again, is an indication of the relatively small permanence in such a system, before pointed out as a probable fact. If there is not much free gas in a nebula, the heat radiated by the meteoric masses into space will be great, because unobstructed by the gas. If, on the other hand, there is much free gas in the nebula, it will fritter the translatory motion down by friction into heat. A translatory motion whose temperature equivalent $\left(36,000^{\circ} \mathrm{C}\right.$. $)$ is from ten to twenty times more than sufficient to volatilize the moving masses, if utilized, could scarcely exist for a lengthened epoch, or this would seem to be an unnatural state of things.

If the meteoric masses had a mean length of path at all comparable in relative scale to that of a gas at normal density ; such as, for instance, if the mean path were (merely for illustration) xooo times the diameter of the meteorite ; then it is evident that the whole system-by a translatory motion of $5 \frac{1}{2}$ kilometres per second--would be resolved into gas in a few minutes or even seconds of time. The question then becomes, as it seems, How far does lengthening the mean path diminish the tendency to resolution into vapour by allowing time to cool between the encounters? or some mechanical relations might possibly be demonstrated here from elements ${ }^{1}$ or physical data determinable apparently.

Paris, February.

\section{Upper Wind Currents over the North Atlantic Doldrums.}

THE following observations were taken on board the steamship Araucania on her voyage from Liverpool to Valparaiso in December last :-

From the Cape Verde Islands down to $9^{\circ} \mathrm{N}$. lat. the surface wind was steadily north-east, but the low clouds came as persistently from south-east, and the middle or high Iayers from south-west.

About $5^{\circ} \mathrm{N}$. the wind worked gradually through east to south-east, and we experienced no calm doldrum, nor even a belt of variable winds. From here to the equator the surface wind remained south-east, while the low clouds came from between south and south-east, but the middle and high layers still passed from south-west.

From the line till about $10^{\circ} \mathrm{S}$, while the surface wind continued to blow from south-east, the high cirrus moved from the north-west.

The circulation of the atmosphere, indicated by these observations, is very different from that described by myself in your columns on two former occasions. On one, while traversing the same track as now, only in the month of July I885; and on another while going from Cape Verde to Cape Town in December of the same year, I found the highest current over the doldrums coming from the east. Now there was no doldrum at all, and though there were 200 miles of latitude between the place where the last south-west highest current and the first north-west highest current were observed, it seems somewhat improbable that there was a narrow belt of high-level east winds between these two currents from some foint of west.

It may be noted that cirrus came from the south-west for about 300 miles of southing over the south-east trade, and that a low current from south-east blew over both trades from $6^{\circ} \mathrm{S}$. to $13^{\circ} \mathrm{N}$.

Straits of Magellan, January I 5 .

The Giant Earthworm of Gippsland.

IN the last issue of NATURE (p. 394) I observe in an article upon Megascolides australis that a supposition is expressed that very large earthworms will be found to occur in South America

I ${ }^{t}$ is said that " The tal energy of agitation in an isotbermal adiabatic sphere is half the potential energy lost in the concentration from a condition of infinite dispersion" (NATuRE, Nov, 29, r888, p. 107). This is apparentily of infinite dispersion (NATURE, Nov. $29, \mathrm{r} 888, \mathrm{p}$. 107). This is apparentiy the analogue of the ratio of Clausius, somewhat differently extressed, viz the ratio between the two parts of the energy, translational and vibrational (internal motion). applicable to a rigid body, and calculated at $\frac{1}{2}$ a priori by Maxwell. I would venture one remark here. It appears evident that if the mean thermal equivalent of half the potential energy lost were all accumulated in the meteorites, they would be volatilized. If, on the other hand, part of this thermal equivalent were dissipated in space by radiation, the meteorites could not possess their natural equivalent of thermal energy due to the translatory motion, and consequently it would seem that in the con tinued effort towards the equalization of these two forms of energy (trans latory and thermal), the translatory motion would with tolerable rapidity degrade down to a value which could no longer support the weight of the superincumbent material. This would be another argument for the small degree of permanence of such a system. as well as in other continents. It may be of a little interest to mention that.I found near the town of Manaos, in Amazonia, in the year 1874 , an earthworm that measured 30 inches in length by $\frac{3}{4}$ inch in greatest breadth. When found, in the early morning, it was quite fresh, though newly dead, being somewhat crushed near one end, probably by some passer-by in the darkness. Unfortunately the worm spoiled in the rum in which I attempted to preserve it.

University of Aberdeen, February 27 .

\section{Weight and Mass.}

Prof. Greenhill seems to have overlooked the fact that my letter in NATURE of February 7 (p. 342) related entirely to procedure in teaching. I merely stated that as the result of experi. ence I have found it absolutely necessary to use terms strictly in the senses assigned to them by definition, and not to use the same term in two senses. I find that it conduces to clearness and accuracy to use the word "pound," for example, only in the sense of a certain quantity of matter, and to use the phrase "weight of a pound" when speaking of the force of gravity on that quantity of matter.

With the ordinary expressions used by engineers when addressing engineers or other persons who, presumably, are able to distinguish between the different senses in which the same term or phrase is used, I have no quarrel whatever, and must decline Prof. Greenhill's invitation to express an opinion as to the accuracy of the phrases which he quotes from NATURE.

University College, Bangor, February 25

A. Gray.

\section{The Formation of Ice.}

IN connection with the discussion on the formation of ice in crystals, it might be worth while to record that on December 6 , $\mathrm{r} 86 \mathrm{I}$, in a slight frost, I saw some in the process of formation in a trough of water. There were three thin pieces of ice in it, two irregular, but the third a beautiful star, 4 or 5 inches in diameter, having six feather-like rays which were branched twice or thrice, in all cases at an angle of $60^{\circ}$. Also, two days before, when the water in the trough was frozen over, I observed in it six-rayed stars several inches in diameter very slightly raised above the rest of the surface.

Sunderland, March 2.

T. W. BACKHOUSE.

\section{ROTIFERA AND THEIR DISTRIBUTION.'}

$\mathrm{T}^{\mathrm{T}}$ is no longer possible, I think, for your President to give, as the substance of his address, a summary of the most important improvements of the microscope, and of the most remarkable results of microscopical research, which have been recorded in the preceding twelve months.

All this is now so fully and so admirably done in your own journal, by your energetic Secretary and his able colleagues, that your Presidents will most probably, in future years, have to follow the excellent precedent set by Dr. Dallinger, and choose for the subject of their address some topic directly springing from their own special studies. For, on an occasion like this, each President would wish to give the Society the best he can, and it is clear that this best must be sought for among matters of which he has a special knowledge.

Unfortunately, an accident, which befell me early last year, not only robbed me of the pleasure of being present at several of your monthly meetings, but also produced consequences that compelled me to put my microscope aside; and, as I had not long before finished my share of the "Rotifera," I feared at first that I had lost the power of pursuing any new investigations, just at the very time when I had published the results of all my old ones.

There is, however, still a portion of my subject with which I am familiar, and which, I believe, has not as yet been touched upon by anyone; and I venture to

I Address delivered at the Annual Meeting of the Royal Microscopical Society, by Dr. C. T. Hudson, President, on February 13 , 1889 . 